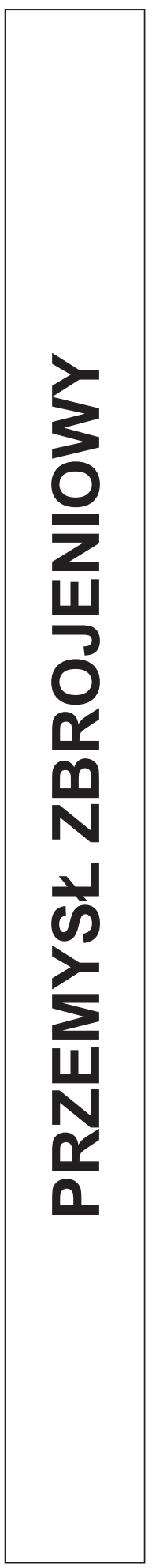



Warszawa

Paweł LUZAK

Uniwersytet im. Adama Mickiewicza w Poznaniu

\section{MIEJSCE, ROLA I ZADANIA POLSKIEGO PRZEMYSLU ZBROJENIOWEGO W SYSTEMIE BEZPIECZEŃSTWA PAŃSTWA}

\section{POLSKI PRZEMYSŁ OBRONNY - PODSTAWOWE INFORMACJE}

Jednym z istotnych elementów, wpływających na obronność państwa, a co za tym idzie kształtujących stan bezpieczeństwa narodowego państw, jest posiadany przez nie przemysłowy potencjał obronny. Stanowi on jedną z pozamilitarnych części składowych systemu obronności państwa, na które składają się ogniwa informacyjne, ochronne i gospodarcze - podmioty wykonawcze administracji publicznej, z wyjątkiem Sit Zbrojnych $R P$, inne instytucje państwowe, a także przedsiębiorcy i stowarzyszenia, na których nakłada się lub którym zleca się wykonywanie zadań obronnych w warunkach obowiązujących przepisów prawnych (Zamiar, Zamiar, 2011: 92). Rozporządzenie Rady Ministrów z 4 października 2010 r. w sprawie wykazu przedsiębiorców o szczególnym znaczeniu gospodarczo-obronnym zawiera listę 177 przedsiębiorstw (po zmianach z 23 grudnia 2013 r.) zobligowanych do wykonywania zadań na rzecz obronności państwa (Rozporzadzenie, 2010).

Polski przemysł obronny tworzy około 150 podmiotów o zróżnicowanym profilu produkcji i wielkości. Jego trzonem i najważniejszym elementem jest przemysłowy potencjał obronny (PPO) definiowany jako, ,[...] zasoby materialne i niematerialne polskiego przemysłu, zaspokajające potrzeby obronne państwa, w tym potrzeby SZ RP dotyczące wyposażenia w uzbrojenie i sprzęt wojskowy" (Biała, 2010: 51). Za podstawę przemysłowego potencjału obronnego Polski uznać można podmioty wymienione w rozporządzeniu Rady Ministrów z 4 października 2010 r. w sprawie wykazu spółek, przedsiębiorstw państwowych i jednostek badawczo-rozwojowych, prowadzących działalność gospodarczą na potrzeby bezpieczeństwa i obronności państwa, a także spółek realizujących obrót z zagranicą towarami, technologiami i usługami o znaczeniu strategicznym dla bezpieczeństwa państwa oraz dla utrzymania międzynarodowego pokoju i bezpieczeństwa (Rozporzqdzanie, 2004). Wśród owych podmiotów gospodarczych znajdują się:

1) spółki prowadzące działalność gospodarczą na potrzeby bezpieczeństwa i obronności państwa, w których właścicielem bezpośrednim lub pośrednim jest Skarb Państwa: Grupa Polskiego Holdingu Obronnego (PHO), obejmująca siedemnaście spółek; Agencja Rozwoju Przemystu, zrzeszająca siedem spółek; Huta Stalowa Wola S.A.; Polska Grupa Zbrojeniowa (PGZ);

2) dziesięć instytutów badawczych; 
3) jedenaście spółek powstałych w wyniku komercjalizacji wojskowych przedsiębiorstw remontowo-produkcyjnych (WPRP);

4) trzy spółki nadzorowane przez Ministra Skarbu Państwa;

5) sześć podmiotów sprywatyzowanych (w tym cztery z udziałem kapitału zagranicznego).

Schemat 1. Przemysłowy potencjal obronny RP

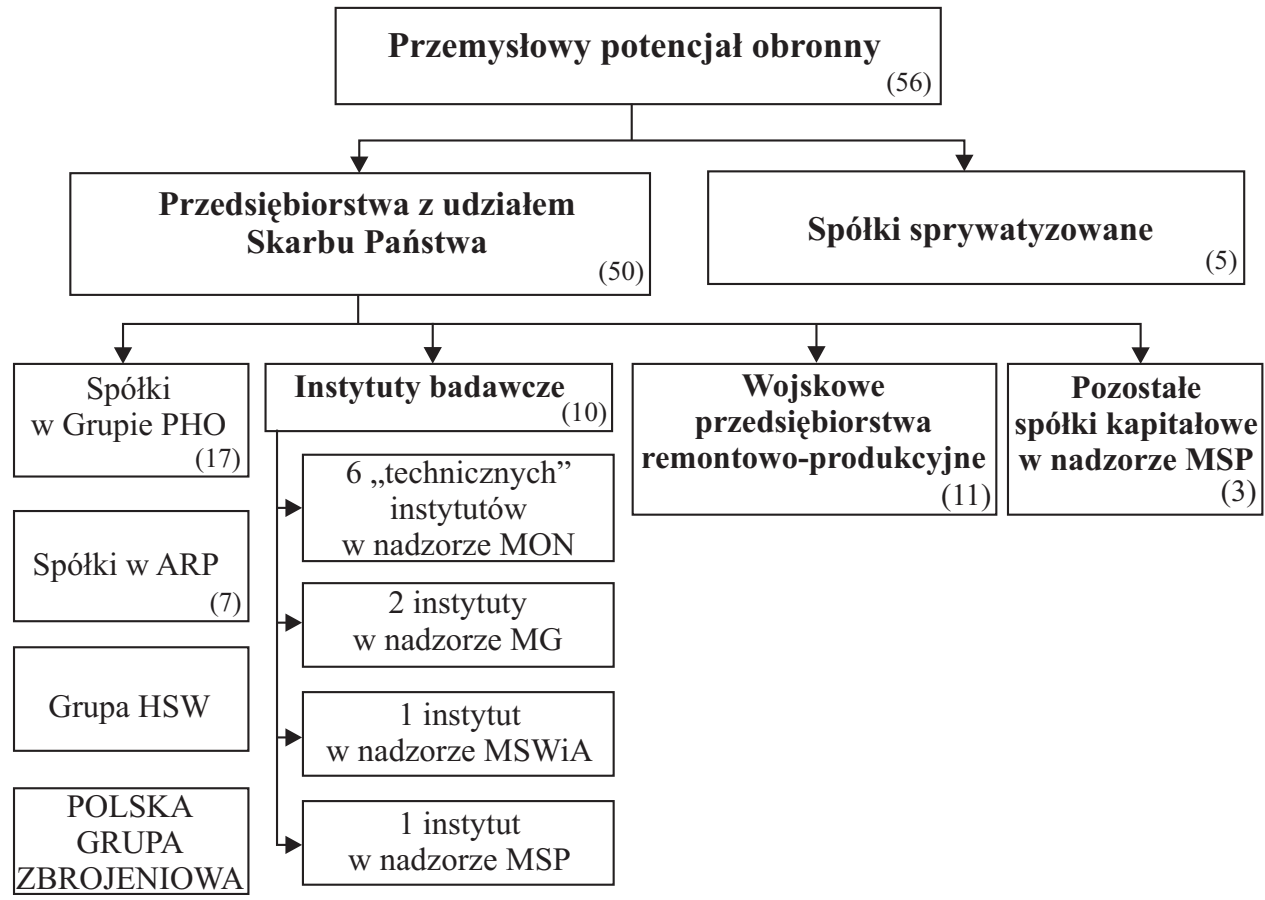

Źródło: Wystapienie gen. W. Skrzypczaka na I Ogólnopolskim Forum Studiów nad Bezpieczeństwem „Człowiek - Technika - Środowisko", Poznań 15.01.2014.

Obecna struktura PPO Polski jest wynikiem trwających (i wciąż niezakończonych) od rozpoczęcia przemian społeczno-ustrojowych procesów restrukturyzacji i konsolidacji sektora obronnego. Zmiany w sferze polityki i gospodarki, a także czynniki takie, jak: załamanie się mechanizmów współpracy w ramach Układu Warszawskiego oraz stopniowa redukcja liczebności sił zbrojnych wymusiły redefinicję zadań i roli polskiego przemysłu zbrojeniowego po roku 1989 (Lewandowski, 2011: 171). Wymienione czynniki doprowadziły do poważnego kryzysu tego sektora przemysłu, szczególnie widocznego w latach 90. XX wieku. W efekcie rozpoczęto procesy restrukturyzacyjne, których egzemplifikacją było opracowanie szeregu programów naprawczych, takich jak: „Projekt przebudowy sektora zbrojeniowego” (przełom 1991 i 1992 r.), „Program komercjalizacji i oddłużenia przemysłu obronnego” (1993 r.), „Program restrukturyzacji sektora przemysłu obronnego i lotniczego na lata 1996-2010”, „Program restrukturyzacji przemysłu obronnego i wsparcia w zakresie modernizacji technicznej Sił Zbrojnych RP”, „Strategia przekształceń strukturalnych przemysłowego potencjału 
obronnego w latach 2003-2005” (,Strategia 2002”) i Strategia konsolidacji i wspierania rozwoju polskiego przemysłu obronnego w latach 2007-2012” („Strategia 2012”). Cele wyznaczone w poszczególnych programach realizowano z różną skutecznością, przy czym żadnego z programów uruchamianych do roku 2001 nie udało się zrealizować w całości. Odegrały one jednak istotną rolą w restrukturyzacji PPO i stanowiły punkt wyjścia do dalszych działań (Lewandowski, 2011: 172-175).

Realizacja „Strategii 2002” przyczyniła się do poprawy sytuacji ekonomiczno-finansowej dużej części podmiotów PPO. Działania podjęte wówczas skupiały się na konsolidacji kapitałowej wybranych spółek. Utworzono wówczas dwie grupy: PHZ Bumar Sp. z o.o. (amunicyjno-rakietowo-pancerną) oraz spółkę lotniczo-radioelektroniczną, w której spółką dominującą została Agencja Rozwoju Przemysłu S.A. (ibidem: 17). Należy podkreślić, że procesy konsolidacji przemysłu zbrojeniowego i działania na rzecz koncentracji produkcji były zjawiskiem typowym dla przemysłów obronnych państw wysoko rozwiniętych po zakończeniu rywalizacji zimnowojennej. Wzmacniało to ich konkurencyjność, także na rynkach zagranicznych (Szegedi, 2001: 40). Stąd w kolejnych latach, mimo pojawiających się problemów, kontynuowano dążenia do pełniejszej konsolidacji PPO Polski. Ich zwieńczeniem jest utworzenie w 2013 r. Polskiej Grupy Zbrojeniowej (PGZ), która została zarejestrowana 5 grudnia 2013 r. W jej skład do 30 czerwca 2014 r. ma wejść około 30 spółek, w tym wszystkie najważniejsze przedsiębiorstwa polskiej ,zbrojeniówki”: spółki Polskiego Holdingu Obronnego, Huta Stalowa Wola S.A., 11 Wojskowych Przedsiębiorstw Remontowo-Produkcyjnych oraz OBR Centrum Techniki Morskiej S.A. (Powstanie, 2013). Konsolidacja PPO przebiegać będzie w dwóch etapach. W pierwszym, do PGZ S.A. wniesione mają zostać akcje i udziały WPRP, OBR Centrum Techniki Morskiej S.A., a także Huty Stalowa Wola S.A. W drugim, którego realizacja przewidziana jest na drugie półrocze 2014 roku, do PGZ dołączyć mają wytypowane spółki zależne od PHO Sp. z o.o. o ustabilizowanej sytuacji ekonomicznej oraz dysponujące określonymi zdolnościami techniczno-produkcyjnymi niezbędnymi do realizacji programów uzbrojenia i programów modernizacji technicznej Sił Zbrojnych RP (Sukces, 2014). Projektowany skład PGZ S.A. przedstawia Schemat 2.

Schemat 2. Projektowany skład Polskiej Grupy Zbrojeniowej

\begin{tabular}{|l|}
\hline 11 WPRP \\
\hline 1. WZMech. S.A. \\
2. WZMot. S.A. \\
3. WZI S.A. \\
4. WZE S.A. \\
5. WZL-1 S.A. \\
6. WZL-2 S.A. \\
7. WZU S.A. \\
8. WZL-1 S.A. \\
9. WZL-2 S.A. \\
10. WZL-4 S.A. \\
11. WCBKT S.A.
\end{tabular}

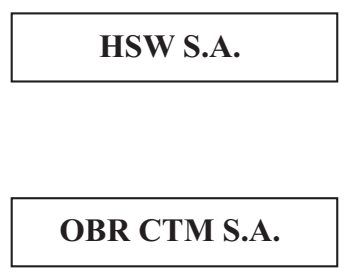

PHO Sp. z o.o.

1. Bumar PCO S.A.

2. Bumar Amunicja S.A.

3. Bumar Elektronika S.A.

4. FB Lucznik Sp. z o.o.

5. ZM Bumar-Labędy S.A.

6. ZM Tarnów S.A.

7. OBRUM Sp. z o.o.

8. PSO Maskpol S.A.

9. CENZIN Sp. z 0.0 .

Źródło: Wystapienie gen. W. Skrzypczaka na I Ogólnopolskim Forum Studiów nad Bezpieczeństwem „Człowiek - Technika - Środowisko", Poznań 15.01.2014. 


\section{ZASADNICZE DOKUMENTY STANOWIĄCE ZAKRES, CEL I ZADANIA POLSKIEGO PRZEMYSLU OBRONNEGO W SYSTEMIE BEZPIECZEŃSTWA PAŃSTWA}

Znaczenie PPO dla bezpieczeństwa narodowego Polski, a także jego istotny wpływ na system bezpieczeństwa narodowego podkreślono w najważniejszych dokumentach określających strategię bezpieczeństwa narodowego Polski: Strategii Bezpieczeństwa Narodowego Rzeczypospolitej Polskiej z 2007 r. (SBN RP), a także Strategii Rozwoju Systemu Bezpieczeństwa Narodowego Rzeczypospolitej Polskiej 2022 (SRSBN RP), będącej jedną z dziewięciu strategii sektorowych do Strategii Bezpieczeństwa Narodowego.

W przyjętej przez Radę Ministrów i zatwierdzonej przez Prezydenta RP 13 listopada 2007 roku SBN RP zaakcentowano znaczenie rozwoju przemysłu obronnego jako istotnego elementu gospodarczej sfery bezpieczeństwa państwa. Strategia podkreśla, że PPO musi ,„...] pozostawać w symbiozie z potrzebami obronnymi, określonymi w programach modernizacji sił zbrojnych, a także być w zgodzie z przyjętymi zobowiązaniami sojuszniczymi w NATO” (Strategia, 2007: 18). Zakłada się, że długoterminowe kontrakty zbrojeniowe o znaczeniu strategicznym powinny gwarantować udział PPO i maksymalizować korzyści dla polskich przedsiębiorstw. Podkreśla się także wage , ,...] napływu do Polski innowacyjnych technologii oraz rozwój powiązań kapitałowych między rodzimymi i zagranicznymi przedsiębiorstwami” (ibidem: 18). Wskazano również konieczność usprawnienia narodowego systemu kontroli eksportu towarów, technologii i usług o znaczeniu strategicznym. Strategia Bezpieczeństwa Narodowego odnosi się także do problematyki zwiększania konkurencyjności polskiego przemysłu obronnego. Podkreślono w niej konieczność kontynuowania procesów restrukturyzacji i konsolidacji, a także ścisłego powiązania z zapleczem naukowo-badawczym. Działania te mają na celu zwiększenie udziału PPO w międzynarodowej współpracy, ze szczególnym uwzględnieniem programów naukowo-badawczych w ramach Europejskiej Agencji Obrony i programów NATO. Celem uzyskania pożądanej intensyfikacji działalności badawczo-rozwojowej na potrzeby obronności oraz zagwarantowania współpracy producentów uzbrojenia i sprzętu wojskowego z instytucjami badawczo-rozwojowymi, autorzy strategii postulują także konsolidację zaplecza badawczo-rozwojowego PPO. Za kluczowe z punktu widzenia pozycji rynkowej przedsiębiorstw przemysłu zbrojeniowego uznają dalszą konsolidację kapitałową sektora i stworzenie efektywnego systemu jego wspierania (ibidem: 18, 30).

Strategia Bezpieczeństwa Narodowego z 2007 r. stanowi bazę koncepcyjną dla przyjętej uchwałą Rady Ministrów z 9 kwietnia 2013 r. Strategii Rozwoju Systemu Bezpieczeństwa Narodowego 2022. W dokumencie tym, będącym jedną z dziewięciu strategii sektorowych do Strategii Bezpieczeństwa Narodowego, podkreślono rolę przemysłowego potencjału obronnego w systemie bezpieczeństwa narodowego państwa, zwracając uwagę na znaczenie polskiego przemysłu, jako kluczowego źródła dostaw uzbrojenia i sprzętu wojskowego, a polskich placówek naukowo-badawczych, jako dostawcy technologii i myśli technicznej w zakresie obronności. Zwrócono także uwagę na czynniki polityczne (dysponowanie potencjałem umożliwiającym produkcję określonych systemów uzbrojenia i sprzętu wojskowego jako wyznacznik suwerenności 
państwa), a także gospodarcze (postęp technologiczny, który rozwój PPO może zagwarantować, generowane miejsca pracy, udział w wymianie handlowej z zagranica, a także przychody budżetu $\mathrm{z}$ tytułu uiszczonych podatków i opłat). W ramach postulatów rozwojowych, mających przyczynić się do umocnienia pozycji rynkowej polskiego przemysłu strategia podkreśla konieczność dokończenia procesów restrukturyzacji sektora, zwiększenia nakładów na badania i rozwój (B+R), konsolidacji zaplecza B+R, a także wsparcia i promocji sektora (Strategia, 2013: 21-22).

Podobnie jak w strategii bezpieczeństwa z 2007 r., również w Strategii Rozwoju Systemu Bezpieczeństwa 2022 podkreślono znaczenie współpracy w ramach Europejskiej Agencji Obrony, a także wielonarodowych programów w ramach NATO, wskazując przy tym istnienie istotnych barier utrudniających efektywne włączenie się PPO do współpracy na rynku europejskim. Autorzy strategii duży nacisk położyli na rozwój zaplecza badawczo-rozwojowego i jego potencjalny wpływ na badania w obszarze bezpieczeństwa. Postuluje się jego konsolidację, co prowadzić ma do zwiększenia konkurencyjności na rynkach europejskim i światowym. Także transfer technologii między sektorami cywilnym i militarnym generuje duże możliwości rozwojowe. Wreszcie, SRSBN RP postuluje utworzenie ,[... ] narodowej grupy kapitałowej przemysłu zbrojeniowego, w której uprawnienia majątkowe powinien wykonywać Skarb Państwa" (postulat ten, zgodnie z przytoczonymi w poprzedniej części artykułu faktami, jest realizowany przez polskie władze) (ibidem: 22-23). SRSBN RP wskazuje działania, których podjęcie ma przyczynić się do rozwoju PPO. Są to (ibidem: 65):

- dostosowanie potencjału produkcyjnego oraz badawczo-rozwojowego przemysłu obronnego do potrzeb odbiorców krajowych oraz możliwości eksportowych;

- opracowanie i wdrożenie systemu pozyskiwania uzbrojenia i sprzętu wojskowego umożliwiającego przewidywalne i w miarę stabilne zamówienia ze strony MON;

- skoordynowanie polityki w zakresie badań naukowych i prac rozwojowych w dziedzinie uzbrojenia i sprzętu wojskowego;

- rozszerzenie oferty asortymentowej przemysłowego potencjału obronnego w zakresie nowoczesnego uzbrojenia i sprzętu wojskowego;

- lokowanie zobowiązań offsetowych w polskim przemyśle obronnym w celu pozyskania niezbędnych zdolności służących zabezpieczeniu realizacji podstawowych interesów bezpieczeństwa i obronności państwa;

- wprowadzanie do umów offsetowych zobowiązań związanych z realizacją programów istotnych dla bezpieczeństwa i obronności państwa;

- włączenie polskich podmiotów do tworzenia innowacyjnej i konkurencyjnej europejskiej bazy technologiczno-przemysłowej sektora obronnego;

- określenie ram instytucjonalno-prawnych pozwalających na transfer technologii wojskowych do sektora cywilnego oraz działań ograniczających bariery dla tego transferu.

Zapisy SBN RP i SRSBN RP wyznaczają miejsce, rolę i znaczenie w systemie bezpieczeństwa narodowego polskiego przemysłu obronnego, stanowią także bazę konceptualną realizacji polityki zbrojeniowej państwa polskiego. Podstawowa rola PPO - dostarczanie uzbrojenia i sprzętu wojskowego niezbędnego do osiągnięcia wymaganych zdolności przez Sity Zbrojne $R P$ realizowana jest przez system pozyskiwania, eksploatacji i wycofywania uzbrojenia i sprzętu wojskowego tych sił. Jego prawne ramy 
wyznacza decyzja nr 72/MON Ministra Obrony Narodowej z 25 marca 2013 r. w sprawie pozyskiwania sprzętu wojskowego i usług dla Sił Zbrojnych Rzeczypospolitej Polskiej, która jest także podstawą realizacji Planu modernizacji technicznej sił zbrojnych w latach 2013-2022.

\section{FUNKCJE PRZEMYSLU OBRONNEGO}

Przemysł obronny z punktu widzenia interesów narodowych spełnia wiele funkcji, wśród których wyznaczyć można funkcje obronne, gospodarcze i funkcje polityczne.

\section{Funkcje obronne}

Realizacja funkcji obronnych objawia się w trzech płaszczyznach:

1) zaspakajania bieżących i perspektywicznych potrzeb w zakresie dostaw, modernizacji, remontów i serwisowania sprzętu wojskowego i środków bojowych;

2) zabezpieczenia eksploatacji sprzętu wojskowego w Siłach Zbrojnych RP;

3) zapewnienia bezpieczeństwa militarnego państwa.

Podstawowymi funkcjami PPO jest zapewnienie gotowości bazy mobilizacyjnej ${ }^{1}$, zaspokajanie bieżących i perspektywicznych potrzeb sił zbrojnych w zakresie dostaw, modernizacji i remontów uzbrojenia, amunicji i sprzętu wojskowego, a także rozwój zaplecza badawczo-rozwojowego. Powyższe zadania odnoszą się zarówno do czasu pokoju, jak i funkcjonowania państwa w warunkach wojny. W tym drugim przypadku w naturalny sposób następuje jednak zwiększenie potrzeb i produkcji sprzętu wojskowego. Stąd konieczność podtrzymywania w czasie pokoju nadwyżek zdolności produkcyjnych. Utrzymywane w stanie uśpienia linie produkcyjne i remontowe moga zostać uruchomione w sytuacji zagrożenia. Zgodnie z planem z programem mobilizacji gospodarki (PMG) określa się także „zadania, jakie mogą być nałożone na przedsiębiorców o szczególnym znaczeniu gospodarczo-obronnym w zakresie dostaw lub remontów uzbrojenia i sprzętu wojskowego [...]" (Ustawa, 2003). W sytuacji wystąpienia kryzysu lub wojny istotna jest także pomoc, jaką w zakresie technologii i kadr otrzymać mogą te podmioty sektora cywilnego, które są w stanie dostosować swoją produkcję do potrzeb sektora militarnego. Następuje wówczas tzw. konwersja gospodarki i dostosowanie produkcji na potrzeby sektora militarnego (Nowak, Nowak, 2011: 85).

Znaczenie przemysłu obronnego dla potrzeb zapewnienia bezpieczeństwa militarnego oraz utrzymania sprawności systemu obronnego i w szerszym wymiarze systemu

1 Definiowanej jako ,połączenie ludzi, instytucji, urządzeń i technologicznego know-how, służących projektowaniu, rozwijaniu, wytwarzaniu i utrzymywaniu uzbrojenia oraz wyposażenia obronnego, przeznaczonych do zapewnienia bezpieczeństwa narodowego"; por. M. Sułek, Programowanie gospodarczo-obronne, Warszawa 2007, s. 47-48. Podana definicja za: R. Cooper, The Economic Dimensions of Security, w: Global Security. North American, European and Japanese Interdependence in the 1990s, (red.) E. Grove, London 1997. 
bezpieczeństwa państwa trudno negować. Państwo, które w odniesieniu do priorytetowych zagadnień ze sfery obronności chce posiadać optymalny poziom samowystarczalności (z uwzględnieniem możliwości ekonomicznych i finansowych, a także istniejących sojuszy i porozumień międzynarodowych) musi mieć na uwadze kondycję i rozwój rodzimego przemysłu zbrojeniowego. Od jego stanu zależy bowiem bezpośrednio potencjał i możliwości sił zbrojnych. Dlatego polski przemysł zbrojeniowy stanowi podstawowe źródło dostaw, modernizacji i remontów uzbrojenia i sprzętu wojskowego dla Sił Zbrojnych RP. Szacuje się m.in., że rocznie około 70\% wydatków Ministerstwa Obrony Narodowej przeznaczonych na modernizację techniczną opiera się na PPO. Wskaźnik ten jest jeszcze wyższy w przypadku Wojsk Lądowych (gdzie szacuje się go na około 90\%) (Idzik, 2011: s. 8). Także realizacja szeroko komentowanego ambitnego Planu modernizacji technicznej sił zbrojnych w latach 2013-2022, którego główne zadania i priorytetowe programy przedstawia tabela 1 oparta będzie na rodzimym przemyśle zbrojeniowym, co wnioskować można z politycznych zapowiedzi dążności do maksymalnej ,,polonizacji” przemysłu obronnego (Premier, 2014; Program, 2014).

Tabela 1

Priorytetowe programy modernizacji Sil Zbrojnych RP w latach 2013-2022 oraz programy modernizacji technicznej poza programami operacyjnymi

\begin{tabular}{|c|c|c|}
\hline Lp. & $\begin{array}{c}\text { Programy Uzbrojenia wymienione } \\
\text { w Planie modernizacji technicznej SZ } \\
\text { w latach 2013-2022 }\end{array}$ & $\begin{array}{l}\text { Modernizacja techniczna } \\
\text { poza programami operacyjnymi }\end{array}$ \\
\hline 1. & Obrona przeciwlotnicza i przeciwrakietowa & Modernizacja czołgów Leopard \\
\hline 2. & Śmigłowce wsparcia bojowego zabezpieczenia i VIP & Wielozadaniowy pojazd Wojsk Specjalnych - Pegaz \\
\hline 3. & $\begin{array}{l}\text { Zintegrowany system wsparcia dowodzenia oraz } \\
\text { zobrazowania pola walki C4ISR }\end{array}$ & $\begin{array}{l}\text { Pozyskanie pozostałych okrętów ujętych w koncep- } \\
\text { cji rozwoju Marynarki Wojennej (o. rozpoznania } \\
\text { elektronicznego, o. wsparcia operacyjnego) }\end{array}$ \\
\hline 4. & $\begin{array}{l}\text { Modernizacja wojsk pancernych i zmechanizowa- } \\
\text { nych }\end{array}$ & Wyposażenie indywidualne żołnierza \\
\hline 5. & Zwalczanie zagrożeń na morzu & Sprzęt inżynieryjny \\
\hline 6. & Rozpoznanie obrazowe i satelitarne & Sprzęt obrony przed BMR \\
\hline 7. & $\begin{array}{l}\text { Indywidualne wyposażenie i uzbrojenie żołnierza } \\
\text { - TYTAN }\end{array}$ & Pojazdy transportowe \\
\hline 8. & Modernizacja Wojsk Rakietowych i Artylerii & $\begin{array}{l}\text { Pojazdy transportowe o przeznaczeniu innym niż } \\
\text { bojowe }\end{array}$ \\
\hline 9. & Symulatory i trenażery & Części zamienne i remonty wyposażenia \\
\hline 10. & Samolot szkolno-treningowy AJT & Zakupy amunicji \\
\hline 11. & Samoloty transportowe & \\
\hline 12. & Kołowe transportery opancerzone & \\
\hline 13. & Przeciwpancerne pociski kierowane & \\
\hline 14. & Rozpoznanie patrolowe & \\
\hline
\end{tabular}

Źródło: Uchwała Nr 164 Rady Ministrów z dnia 17 września 2013 roku w sprawie ustanowienia wieloletniego programu „Priorytetowe Zadania Modernizacji Technicznej Sił Zbrojnych Rzeczypospolitej Polskiej w ramach programów operacyjnych”, Poz. 796. Wystapienie gen. W. Skrzypczaka na I Ogólnopolskim Forum Studiów nad Bezpieczeństwem „Człowiek - Technika - Środowisko”, Poznań 15.01.2014. 
Priorytetowe programy modernizacji technicznej polskiej armii, a także wysokość środków, które planuje się na nią przeznaczyć ${ }^{2}$ stanowią jednocześnie szansę i poważne wyzwanie dla polskiej „zbrojeniówki”. Poczynione już i opisane w poprzedniej części artykułu kroki, związane z konsolidacją sektora obronnego w ramach PGZ to działania, które mają umożliwić polskiemu przemysłowi obronnemu realizację dużych projektów. Elementem kluczowym pozostaje natomiast potencjał technologiczny i możliwość sprostania wymogom polskiej armii, które zdecydują o tym czy PPO wykorzysta szansę, jaką są dla niego rosnące nakłady na modernizację sił zbrojnych. Wśród polityków, zapewnieniom o preferencjach dla polskiego przemysłu towarzyszy bowiem wyraźne zastrzeżenie, że to jakość oraz nowoczesność uzbrojenia i sprzętu wojskowego będą najważniejszym kryterium przy wyborze partnerów do współpracy (Sukces, 2014).

\section{Funkcje gospodarcze}

Bezpośredni związek między kondycją rodzimego przemysłu zbrojeniowego a stanem i możliwościami sił zbrojnych, a co za tym idzie potencjałem obronnym państwa, determinuje jego znaczenie dla szeroko pojętej sfery obronności. PPO ma jednak dla państwa duże znaczenie także w aspektach stricte gospodarczych.

Pierwszym z tych aspektów jest wielkość zatrudnienia generowanego przez przemysł zbrojeniowy. Szacuje się, że tylko w ramach tworzonej grupy PGZ zatrudnionych będzie około 14 tysięcy pracowników. Liczba pośrednio stworzonych i utrzymanych miejsc pracy może natomiast sięgnąć nawet $40-50$ tysięcy (ibidem). Po drugie, należy mieć na uwadze, że pieniądze zainwestowane w polski przemysł obronny trafiają do polskiej gospodarki, a co za tym idzie mogą i powinny być czynnikiem stymulującym rozwój gospodarczy i przyrost PKB. Mają to na uwadze środowiska polityczne, deklarując maksymalne zaangażowane $\mathrm{PPO}$ w realizację programów modernizacji sił zbrojnych $(S K O N, 2013)$. Ponadto polskie firmy płacą podatki w Polsce - w ten sposób część zainwestowanych pieniędzy pośrednio wraca do budżetu państwa. Potencjalne korzyści dla sektora obronnego, jak i gospodarki jako całości są podstawą postulowanej ,polonizacji” przemysłu zbrojeniowego. Bardzo istotne jest bowiem, by pieniądze wydawane za granicą wiązały się nie tylko z zakupem gotowego sprzętu, ale także z produkcją zakupionego sprzętu w Polsce (co znów ma przełożenie na wspomniane wcześniej efekty związane z rynkiem pracy i stymulacja gospodarki). Oczekiwanym skutkiem takiej strategii jest jednak przede wszystkim transfer technologii w ramach

2 Według uchwały nr 164 Rady Ministrów z 17 września 2013 r. w sprawie ustanowienia wieloletniego programu „Priorytetowe Zadania Modernizacji Technicznej Sił Zbrojnych Rzeczypospolitej Polskiej w ramach programów operacyjnych" wydatki na obronność nie będą niższe, aniżeli przewidziane w ustawie z 25 maja 2001 roku o przebudowie i modernizacji technicznej oraz finansowaniu Sił Zbrojnych Rzeczypospolitej Polskiej 1,95\% PKB. Z tego około 131,4 miliarda złotych przeznaczonych ma zostać na modernizację techniczną Sit Zbrojnych RP. Ponad 91,5 miliarda z tej kwoty pochłonąć ma realizacja wymienionych 14 planów operacyjnych (w tym 15937,1 miliona w latach 2014-2016). Dodatkowo prawie 40 miliardów złotych przeznaczone zostanie na zakup sprzętu i wyposażenia nie objętego programami operacyjnymi. 
konsorcjów tworzonych przez zagraniczne firmy i polskie podmioty, umożliwiający polskim przedsiębiorstwom produkcję komponentów pozyskanego uzbrojenia, a także samodzielne wykonywanie napraw i usług serwisowych, modernizację, a nawet eksport sprzętu na rynki międzynarodowe (Pierwszy, 2013; Idzik, 2011: 11; Premier, 2014).

Z punktu widzenia gospodarki państwa rozwój technologii wojskowych jest istotny nie tylko z uwagi na potencjał technologiczny rodzimego przemysłu zbrojeniowego. Technologie wojskowe bardzo często zasilają bowiem sektor cywilny, przyczyniając się do zwiększenia konkurencyjności produktów tego sektora. W państwach zachodnich wykorzystanie technologii wojskowych w gospodarce jest mocno upowszechnione, stąd między innymi tendencja do współfinansowania prac badawczo-rozwojowych na rzecz przemysłu obronnego przez sektor publiczny i podmioty prywatne, zainteresowane cywilnym wykorzystaniem tworzonych technologii - tzw. „technologii podwójnego zastosowania" (ang. Dual-use technology) (Mierczyk, 2011: 48-49). W tej sytuacji nakłady poniesione na rozwój technologii militarnych stanowią inwestycję i element polityki innowacyjnej państwa (Klimiuk, 2011: 79).

Należy przy tym podkreślić, że prostszą i bezpieczniejszą drogą pozyskiwania technologii wydaje się być zakup licencji, bardzo ważnym pozostaje samodzielne finansowanie sfery naukowo-badawczej celem rozwoju własnych innowacyjnych rozwiązań technologicznych (Bartosiewicz, Synowiecki, Wojciechowski, 2011: 86-89). Potrzeba ta znajduje odzwierciedlenie między innymi w przyjętej przez Ministerstwo Obrony Narodowej „Strategii działań resortu obrony narodowej w obszarze badań i technologii obronnych" z 2011 roku, a także przygotowanym przez MON w tym samym roku ,Planie działania na rzecz osiagania celów przewidzianych strategią działań resortu obrony narodowej w obszarze badań i technologii wojskowych". Oba dokumenty zwracają uwagę na konieczność połączenia wysiłków środowisk: wojskowego, przemysłowego i naukowego, celem odpowiedniego ukierunkowania prac badawczych i strategii podmiotów przemysłowych, co powinno umożliwić (Strategia, 2011: 7):

1) zharmonizowanie realizowanych działań $w$ obszarze badań i technologii z potrzebami użytkownika końcowego oraz zapewnienie możliwości wdrożenia rezultatów badań naukowych na potrzeby Sił Zbrojnych RP;

2) ukierunkowanie wysiłków środowiska naukowego realizującego projekty w obszarze bezpieczeństwa i obronności finansowane z budżetu MON oraz ministra właściwego ds. nauki na priorytetowe potrzeby definiowane przez Ministerstwo Obrony Narodowej i Ministerstwo Spraw Wewnętrznych;

3) zwiększenie skali udziału resortu obrony narodowej w międzynarodowych programach i projektach naukowo-badawczych.

Wskazanym w dokumencie celom ogólnym towarzyszą określone cele szczegółowe, których realizacja ma przyczynić się do ich osiagnięcia (Strategia, 2011: 7-12; Plan, 2011: 5-12). O świadomości znaczenia rozwoju bazy naukowo-badawczej dla potrzeb przemysłu obronnego świadczy też między innymi decyzja z marca $2013 \mathrm{r}$. o utworzeniu odrębnego Inspektoratu Implementacji Innowacyjnych Technologii Obronnych $\mathrm{w}$ ramach struktur MON, którego zadania obejmują opiniowanie projektów badawczych dotyczących wojskowości (które mogą otrzymać na ich realizację środki z Narodowego Centrum Badań i Rozwoju), a także wdrażanie nowych technologii w wojsku (Armia, 2013). 


\section{Funkcje polityczne}

Polityczne znaczenie i funkcje przemysłowego potencjału obronnego wynikają pośrednio z jego znaczenia obronnego i gospodarczego. Stan i potencjał PPO wpływa bowiem $\mathrm{z}$ reguły bezpośrednio na potencjał sił zbrojnych państwa. Ten natomiast jest w dalszym ciagu podstawowym wyznacznikiem potęgi państwa i możliwości jego oddziaływania na arenie międzynarodowej.

Potencjał militarny określany przez pryzmat własnych możliwości ekonomicznych i technologicznych, umiejętności administracyjnych i politycznej bazy potęgi militarnej był przedmiotem badań Klausa Knorra. Badacz ten podkreślał, że zdolności mobilizacji zasobów i rozwoju sił zbrojnych zależne są przede wszystkim od możliwości produkcji przez podmiot różnorodnych dóbr i usług. Potencjał militarny i baza przemysłowa są także jednym z elementów składowych tworzących potęgę państwa w modelu Franka Clifforda Germana ${ }^{3}$. Również w modelu Raya S. Cline'a istotnym elementem potęgi państwa są zarówno potencjał gospodarczy, jak i potencjał militarny ${ }^{4}$ (Sułek, 2004: 79-85).

Przemysłowy potencjał obronny, będąc istotnym czynnikiem oddziałującym na potencjał militarny państwa, wpływa na jego pozycję międzynarodową, prestiż i możliwości ochrony interesów narodowych. Jest także istotnym czynnikiem, który decydenci polityczni muszą brać pod uwagę w procesie formułowania strategii państwa. To także ważny element odstraszania potencjalnych agresorów (państwa będące w stanie w czasie wojny szybko i skutecznie zmobilizować gospodarkę w oparciu o własny potencjał przemysłowy posiadają istotną przewagę względem państw - importerów uzbrojenia).

\section{OCZEKIWANIA WOBEC POLSKIEGO PRZEMYSLU OBRONNEGO}

W kontekście przeprowadzonego wywodu przedstawić można główne oczekiwania stawiane przed polskim przemysłem obronnym celem poprawy jego kondycji i stworzenia warunków rozwoju. Obecną kondycję PPO należy bowiem uznać za niezadawalającą. Przy rosnącej konkurencji i szybko konsolidującym się rynku, brak zmian może doprowadzić do marginalizacji polskiej „zbrojeniówki” jako gracza na międzynarodowym rynku zbrojeniowym, jak i ograniczyć możliwości sprostania wymogom Sit Zbrojnych $R P$, jako głównego odbiorcy uzbrojenia i sprzętu wojskowego produkowanego przez PPO.

W ostatnich latach podjęto kroki, których realizacja powinna być punktem wyjścia dla dalszego rozwoju przemysłowego potencjału obronnego Polski. Przede wszystkim utworzenie Polskiej Grupy Zbrojeniowej wydaje się być szansą na faktyczną konsoli-

3 Według modelu F. C. Germana $G=N(L+P+I+M)$, gdzie: $G$ - potęga państwa, $N$ - potencjał nuklearny, $L$ - terytorium, $P$ - ludność, $I$ - baza przemysłowa, $M$ - potencjał militarny.

${ }^{4}$ Według modelu R. S. Cline'a $P_{p}=(C+E+M) \times(S+W)$, gdzie: $P_{p}$ - postrzegana potęga państwa, $C$ - masa krytyczna ludności i terytorium, $E$ - potencjał gospodarczy, $M$ - potencjał militarny, $S$ - strategia państwa, $W$ - wola urzeczywistnienia strategii państwa. 
dację sektora, co z kolei jest warunkiem sine qua non budowy pozycji konkurencyjnej przemysłu zbrojeniowego. Realizacji wymaga także zarysowany w poprzedniej części artykułu (i znajdujący odzwierciedlenie między innymi w zapisach Strategii Rozwoju Systemu Bezpieczeństwa Narodowego 2022) postulat kooperacji sfery naukowo-badawczej i techniczno-produkcyjnej, co wymaga pogłębienia współpracy między poszczególnymi podmiotami, tworzącymi PPO.

Kontynuacji wymaga także prowadzona od jakiegoś czasu polityka kreowania konsorcjów w powiązaniu z konkretnymi programami modernizacyjnymi. Firmy poszukujące odpowiednich partnerów i tworzące konsorcja zadaniowo-biznesowe są z reguły dobrze przygotowane do udziału w programach modernizacji. Przykładem skutecznej realizacji takiej strategii jest np. Polskie Konsorcjum Stoczniowe i przygotowanie programu Kormoran, a także realizacja programów: pancernego (cztery konsorcja polskich firm powstały celem opracowania dla Sit Zbrojnych RP czołgu podstawowego, bojowego wozu piechoty, kołowego transportera opancerzonego, a także modernizacji czołgów Leopard 2A4) i silnikowego (współpraca Wojskowych Zaktadów Motoryzacyjnych S.A. z niemiecką MTU Friedrichshafen GmbH) (Dialog, 2013; Silniki, 2013; Konsorcja, 2013). Celem państwa powinno być wykreowanie dogodnych warunków do powstawaniu konsorcjów zadaniowo-biznesowych, a także właściwy nadzór nad umowami korporacyjnymi (w celu uniknięcia wzrostu kosztów). Powoływane konsorcja powinny odpowiadać za produkcję i utrzymanie w sprawności sprzętu przez cały okres eksploatacji, zabezpieczając potrzeby serwisowania, remontów i modernizacji.

W poprzedniej części artykułu podkreślono także potrzebę uzależnienia zagranicznych zakupów uzbrojenia i sprzętu wojskowego od ulokowania w Polsce procesów produkcyjnych i świadczenia związanych z tym usług (w ramach tzw. „polonizacji” przemysłu zbrojeniowego lub offsetu) celem uzyskania dostępu do technologii obsługowo-remontowej (w tym dokumentacji technicznej i aparatury kontrolno-pomiarowej). Przyjęcie tej strategii działań byłoby elementem stymulującym rozwój potencjału i możliwości rodzimej „zbrojeniówki”, stąd zakupy te powinny dotyczyć tych technologii, których aktualnie w Polsce nie ma.

PPO musi posiadać możliwości dostarczania Siłom Zbrojnym RP najnowocześniejszego i najbardziej zaawansowanego technologicznie sprzętu, zapewniającego możliwość użytkowania przez okres kilkunastu-kilkudziesięciu lat. Oferowany sprzęt powinien także spełniać wymogi interoperacyjności i kompatybilności w kontekście współpracy z sojusznikami. Kolejnym z wymogów jest otwarta, elastyczna i modułowa konstrukcja systemów, umożliwiająca dostosowanie do potrzeb w ramach realizowanych przez wojsko zadań, a także obniżająca koszty produkcji, użytkowania, serwisowania i naprawy.

Implementacja postulowanych zmian i strategii powinna przyczynić się do osiagnięcia pożądanych efektów, wśród których najważniejszymi są:

1) poprawa efektywności wydatkowania środków publicznych - możliwa do osiagnięcia poprzez synergię działań resortów: obrony narodowej, nauki i Skarbu Państwa ukierunkowanych na zaspokajanie potrzeb Sit Zbrojnych RP i struktur bezpieczeństwa państwa w perspektywie krótkookresowej (2 lata) i długookresowej (10 lat i dłużej); 
2) wzmocnienie pozycji polskiego przemysłu obronnego na rynkach międzynarodowych - europejskim i globalnym poprzez: zwiększenie udziału podmiotów PPO w zamówieniach na prace badawczo-rozwojowe i dostawy sprzętu i uzbrojenia wojskowego dla sił zbrojnych;

3) poprawa konkurencyjności PPO na rynku polskim i międzynarodowym rynku sprzętu wojskowego przez zwiększanie możliwości pozyskiwania nowych technologii.

Realizacja wyżej wymienionych celów przyczyniłaby się do poprawy kondycji, rozwoju i zwiększenia konkurencyjności PPO. Znaczna część z nich znajduje odzwierciedlenie w przyjmowanych dokumentach, a także w sferze deklaratywnej, choć nie zawsze ma to bezpośrednie przełożenie na podejmowane działania. $Z$ uwagi na rolę, jaką w zapewnieniu bezpieczeństwa militarnego państwa odgrywają możliwości państwowego przemysłu obronnego, ich urzeczywistnienie leży w najlepszym interesie państwa polskiego i powinno stanowić jeden z priorytetów szeroko rozumianej polityki bezpieczeństwa Polski.

\section{Bibliografia}

Armia stawia na zdolnych cywilów (2013), http://www.rp.pl/, 17.03.2014.

Bartosiewicz A., Synowiecki A., Wojciechowski P. (2011), Wpływ posiadania własnych technologii z dziedziny obronności na wzrost potencjału obronnego kraju i zdolności ekonomicznych podmiotów na przykładzie Radmor S.A. i WB Electronics S.A., w: Modernizacja Wojsk Ladowych impulsem rozwojowym dla polskiej gospodarki, (red.) P. Soroka, Warszawa.

Biała Księga Bezpieczeństwa Narodowego Rzeczypospolitej Polskiej (2013), Biuro Bezpieczeństwa Narodowego, Warszawa.

Dialog o kontraktach bez lobbystów, Wywiad z gen. W. Skrzypczakiem, http://www.polska-zbrojna.pl/, 18.03.2014.

Idzik M. (2011), Wyzwania w planie modernizacji technicznej Wojsk Ladowych a możliwości zaangażowania w ich realizacje polskiego przemystu obronnego, w: Modernizacja Wojsk Ladowych impulsem rozwojowym dla polskiej gospodarki, (red.) P. Soroka, Warszawa.

Konsorcja dla programów pancernych (2013), http://www.altair.com.p1/, 18.03.2014.

Lewandowski W. (2011), Polski przemystowy potencjat obronny w dobie konsolidacji, „Bezpieczeństwo Narodowe", nr 1.

Mierczyk Z. (2011), Technologie podwójnego zastosowania szansa polskiego przemystu, w: Modernizacja Wojsk Ladowych impulsem rozwojowym dla polskiej gospodarki, (red.) P. Soroka, Warszawa.

Nowak E., Nowak M. (2011), Zarys teorii bezpieczeństwa narodowego, Warszawa.

Pierwszy wywiad ze Skrzypczakiem po dymisji: Musimy być gotowi na naciski firm zbrojeniowych i rząów (2013), Wywiad z gen. Waldemarem Skrzypczakiem, http://www.gazetaprawna.pl/, 17.03.2014.

Plan działania na rzecz osiagania celów przewidzianych strategia działań resortu obrony narodowej w obszarze badań i technologii wojskowych (2011), Warszawa.

Powstanie Polska Grupa Zbrojeniowa (2013), http://www.wyborcza.biz, 10.03.2014.

Premier: maksymalna polonizacja przemystu zbrojeniowego (2014), http://wyborcza.pl/, 12.03.2013. 
Program modernizacji będzie kontynuowany (2014), Wywiad z wiceszefem MON Czesławem Mroczkiem, http://www.polska-zbrojna.pl, 13.03.2014.

Rozporzq̨dzenie Rady Ministrów z 4 października 2010 roku w sprawie wykazu przedsiębiorców o szczególnym znaczeniu gospodarczo-obronnym, Dz. U. 2004, Nr 198, poz. 1314 z późń. zm.

Rozporzadzenie Rady Ministrów z 4 października 2010 roku w sprawie wykazu spótek, przedsiębiorstw państwowych i jednostek badawczo-rozwojowych, prowadzacych działalność gospodarczq na potrzeby bezpieczeństwa i obronności państwa, a także spótek realizujacych obrót z zagranica towarami, technologiami i ustugami o znaczeniu strategicznym dla bezpieczeństwa państwa oraz dla utrzymania międzynarodowego pokoju i bezpieczeństwa, Dz. U. 2010, $\mathrm{Nr}$ 198, poz. 1313.

Silniki dla wojska zbuduja w Poznaniu (2013), http://www.polska-zbrojna.pl/, 18.03.2014.

SKON o przebudowie, modernizacji i finansowaniu Sit Zbrojnych RP (2013), http://mon.gov.pl/, 15.03.2014.

Strategia Bezpieczeństwa Narodowego Rzeczypospolitej Polskiej (2007), Warszawa.

Strategia działań resortu obrony narodowej w obszarze badań i technologii obronnych (2011), Warszawa.

Strategia Rozwoju Systemu Bezpieczeństwa Narodowego Rzeczypospolitej Polskiej 2022 (2013), Warszawa.

Sukces modernizacji armii szansq dla zbrojeniówki (2014), http://mon.gov.pl/, 17.03.2014.

Sułek M. (2004), Metody i techniki badań stosunków międzynarodowych, Warszawa.

Sułek M. (2007), Programowanie gospodarczo-obronne, Warszawa.

Szegedi L. (2001), System rzadowego wsparcia dla przemystu obronnego w krajach Europy Zachodniej i NATO, w: Czy przemyst obronny wymaga obrony?, (red.) J. Klich, Kraków.

Uchwała nr 164 Rady Ministrów z 17 września 2013 roku w sprawie ustanowienia wieloletniego programu ,Priorytetowe Zadania Modernizacji Technicznej Sił Zbrojnych Rzeczypospolitej Polskiej w ramach programów operacyjnych”, poz. 796.

Ustawa z 23 sierpnia 2001 roku o organizowaniu zadań na rzecz obronności państwa realizowanych przez przedsiębiorców, Dz. U. 2001, Nr 122 poz. 1320 z późń. zm.

Zamiar P., Zamiar Z. (2011), Pozamilitarne ogniwa w systemie bezpieczeństwa militarnego państwa, „Zeszyty Naukowe WSOWL”, nr 4 (162).

\section{STRESZCZENIE}

Jednym z elementów, wpływających na obronność państwa i kształtujących stan bezpieczeństwa narodowego państw jest posiadany przez nie przemysłowy potencjał obronny. Stanowi on jedną z pozamilitarnych części składowych systemu obronności państwa. Polski przemysł obronny tworzy około 150 podmiotów o zróżnicowanym profilu produkcji i wielkości. Podstawę przemysłowego potencjału obronnego Polski stanowią podmioty wymienione w rozporządzeniu Rady Ministrów z 4 października 2010 r. w sprawie wykazu spółek, przedsiębiorstw państwowych i jednostek badawczo-rozwojowych, prowadzących działalność gospodarczą na potrzeby bezpieczeństwa i obronności państwa, a także spółek realizujących obrót z zagranicą towarami, technologiami i usługami o znaczeniu strategicznym dla bezpieczeństwa państwa oraz dla utrzymania międzynarodowego pokoju i bezpieczeństwa. Obecną kondycję PPO należy uznać za niezadawalającą. Przy rosnącej konkurencji i szybko konsolidującym się rynku, brak zmian może doprowadzić do marginalizacji polskiej „zbrojeniówki”. 
